\title{
FINANCE BUSINESS PARTNERING AND MANUFACTURING FIRMS' PERFORMANCE: A MEDIATING ROLE OF NON-FINANCIAL PERFORMANCE
}

\author{
Yi Fei ZHANG (D) 1,2*, Mohammad NAMAZI ${ }^{3}$, Yong Qing GUO (D) ${ }^{1}$, Xuan LI (D) 4 \\ ${ }^{1}$ Shanghai National Accounting Institute, Shanghai, China \\ ${ }^{2}$ School of Business, Chengdu University, Chengdu, China \\ ${ }^{3}$ Department of Accounting, Shiraz University, Shiraz, Iran \\ ${ }^{4}$ School of Accounting, Shandong Technology and Business University, Yantai China
}

Received 24 Jun 2019; accepted 06 January 2020

\begin{abstract}
The effect of finance business partnering (FBP) implementation on the firm performance remains largely unexplored. The main aims of this study are to investigate whether there is a significant effect between FBP and firm performance and to identify the mediating effect of non-financial performance between FBP and firm performance. A questionnaire-based survey was conducted among 117 Chinese manufacturing firms in the year 2018, and research hypotheses were tested by partial least squares structural equation modelling (PLS-SEM). The findings showed that 1) FBP does not exert a significant and direct effect on the firms' financial performance, 2) when non-financial measures (employees performance, internal process performance, and market performance) are used as mediating variables, the effect of all the three mediating variables on the relationship between FBP and non-financial variables are positive and significant. However, when the relationship between non-financial measures and firm's performance is considered, the mediating effect of the non- financial variables is positive and significant only for the market performance. This study provides, for the first time, empirical evidence that non-financial performance, such as employee skills, internal processes, and market performance, can be enhanced by considering FBP. It also provides practical implications suggesting that manufacturing firms should motivate finance staff to be involved in various decision-making processes.
\end{abstract}

Keywords: finance business partnering, manufacturing firms, financial performance, non-financial performance, survey, China.

JEL Classification: M41, C83, L20.

\section{Introduction}

Manufacturing firms play a key role in the development of every economy, including China's economy. In May 2015, the State Council of China promulgated the blueprint for "The Imple-

*Corresponding author. E-mail: zhang_frank20032003@yahoo.co.uk

This is an Open Access article distributed under the terms of the Creative Commons Attribution License (http://creativecommons. org/licenses/by/4.0/), which permits unrestricted use, distribution, and reproduction in any medium, provided the original author and source are credited. 
mentation of China Manufacturing 2025”, which also marked the beginning of the transition from the traditional manufacturing industry to a more advanced industrial economy, which is called industrial 4.0. Currently, manufacturing firms in China are operating in a rapidly changing and competitive environment, and they need to obtain accurate information for business decision making and to continuously improve their performance and sustain their competitive advantages. Under these circumstances, finance departments must shift their roles from data recording to assisting in decision-making processes (CGMA, 2015). Companies must also consider finance to be a business partner rather than a policeman (Zoni \& Merchant, 2007), an approach known as "finance business partnering" (FBP). In 2015, The Chartered Global Management Accountant (CGMA) stressed that FBP can play an active role in enhancing the quality of decisions and ensuring the long-term success of business. Many Chinese scholars also consider FBP to be among the influential factors affecting the foundation of successful improvements in business performance.

Despite the discussions regarding the important role of FBP on firms' financial performance, to date, existing studies have examined the effect of some factors on firms' financial performance, such as corporate governance (Ciftci et al., 2019; Hussain et al., 2018; Achim et al., 2016) and corporate social responsibility (Hasan et al., 2018; Sun et al., 2019). However, no study has deeply tested the relationship between FBP and firms' financial performance empirically. In addition, the role of non-financial measures has not been explored in this context. Previous studies have investigated the influence of the controllers on the firms' performance, and contradicting results have been presented. Some studies have shown that participation of the controllers in FBP results in the improvement of the firms' performance (Zoni \& Merchant, 2007). However, other studies have found that FBP leads to a decrease in firms' performance due to the influence of "organizational slacks" (Indjejikian \& Matejka, 2006). These contradictory results fail to answer key questions: Does the implementation of FBP can lead to the improvement of firms' performance? And what is the effect of the nonfinancial factors in this regard? Understanding the relationship between firms' performance and FBP, as well as the role of non-financial information in this context, is very important for management strategies and business development.

Therefore, the main objectives of this study are to investigate 1) the extent to which FBP has been implemented among Chinese manufacturing firms; 2) whether there is a significant relationship between the target financial performance of the firms and FBP in terms of sales volume, profit or reduction in cost; 3)whether the relationship between the degree of FBP implementation and target financial performance is mediated by non-financial performance; and 4) whether there is a significant relationship between FBP and the target non-financial performance of the firms in terms of product quality, customer satisfaction, and market share.

To achieve the stated research objectives, survey data were collected from chief financial officers (CFOs) and finance directors of 117 manufacturing firms in China. CFOs or finance directors are responsible for the design of management control systems, should possess clear knowledge of the operational systems of the firm, and might have power to influence decision-making. Data analysis was conducted by using partial least squares (PLS), which is a popular tool for business research (Hair et al., 2014). The results show that there is no 
significant and direct relationship between FBP implementation and firms' financial performance and that non-financial performance criteria, with market performance as a mediating variable, significantly affect the relationship between FBP and firms' financial performance.

This research makes four main contributions. First, raises awareness concerning FBP elements and the benefits of FBP among Chinese manufacturing firms. Second, it is the first study that attempts to determine the effects of certain important indicators of FBP on firms' financial performance. Third, this study extends the theory of the existing literature in this area by asserting that the effect of the relationship between FBP and firms' financial performance can be improved by considering the mediating effect of non-financial factors between FBP and firms' financial performance. Fourth, it presents relevant empirical results and provides useful implications on the effect of FBP on firms' financial performance.

The remainder of this study is structured as follows: the theoretical framework, relevant literature review and hypotheses are provided in Section 1; Section 2 describes the research method, including the design of the questionnaires, the measurement of the main research variables, and the theoretical research framework; Section 3 presents the results of testing the main hypotheses; Section 4 provides a discussion and conclusions. Last section presents the suggestions and limitations.

\section{Theoretical research framework and hypothesis development}

The general theoretical basis of this study focuses on the "contingency theory". This theory is widely used in management accounting and control system research. It contends that there is no universal managerial accounting system (MACS) that is appropriate for every organization. Rather, devising a MACS is based on the exogenous and endogenous variables pertaining to the organization, and each organization should establish an appropriate system in compliance with its peculiarities. The effectiveness of the MACS depends on whether its design can be matched with the surrounding environment, technological factors, company size, and company strategy (Fisher, 1995; Chenhall, 2003). Chenhall (2003), McAdam et al. (2019), Zhang et al. (2017) and others have shown that contingency theory is appropriate for establishing an effective MACS, and an effective MACS will have a positive impact on the firms' performance. Hence, contingency theory is generally suitable for this study.

The specific theory underlying this study, however, is based on the concept of the "value relevance theory". This theory, as it pertains to the purpose of this study and as described by CGMA (2015) and GMAP (2016), states that today, the environment of business firms is significantly different from that in prior periods. The current environment of the business firms can be characterized by the geo-political term VUCA: Volatile, Uncertain, Complex, and Ambiguous. As a result, attainment of the competitive advantages of firms and their business decisions are much more subtle than before. Consequently, the role of the finance department should be changed from its traditional scorekeeping function to FBP; that is, the efforts of the department of finances should be directed towards value creation - attaining profitability, efficiency, sustainable competitive advantages, and value creation for all stakeholders, and not just stockholders, and devising advanced performance evaluation systems. 
Figure 1 shows the theoretical framework of this study. The elements and paths of the relationships among variables are explained based on the preceding theories and the current literature in this domain.

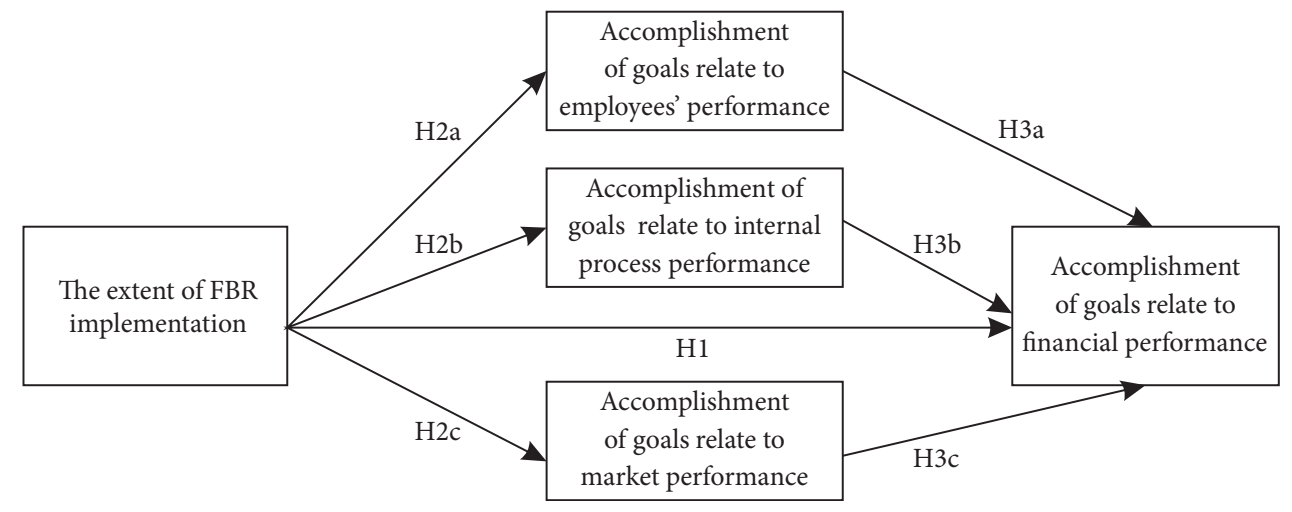

Figure 1. Theoretical research framework

\subsection{Effect of FBP on firm's financial performance}

Figure 1 shows that there is a direct path relationship (H1) between the extent of the involvement of the FBP and attainment of the goals related to the firm's financial performance. The description of the elements of this relationship is as follows:

To date, few studies have provided a formal definition of FBP. The Ministry of Finance of China defines FBP as cooperation between various departments of the firm and the finance department to make different decisions pertaining to planning, controlling, coordination and evaluation through the application of advanced technology to achieve real-time sharing of data flow, capital flow, information flow and other data sources ${ }^{1}$. FBP is also defined as the role that finance departments play in creating value by improving the quality of decisions regarding financing and cost control pricing (Flanagan \& Grant, 2013). CGMA (2015, p. 20) defines FBP as "where accounting disciplines and business understanding are combined to provide analysis or insights to inform and influence decision making and performance management, preserving or improving value generation in the interests of a business' stakeholders". To develop superior measures for the main research variables, the domain of the construct should be accurately specified. The important step in specifying the domain of the construct is to decide which definition should be included or excluded (Churchill, 1979).

Existing studies have also argued that financial officers (management accountants) should be business oriented by being involved in the decision-making processes of the firm (Burns \& Baldvinsdottir, 2005; Jarvenpaa, 2007). In addition, Graham et al. (2012) asserted that finance departments should provide support to decision-making by acting as internal consultants to other departments. CGMA (2015) also noted that FBP should provide assistance with decision making (1) at the group level, such as strategic determination; (2) at the business unit level, such as budgeting, merging and acquisition; and (3) in performance management,

\footnotetext{
${ }^{1}$ Source: "Basic guidelines for management accounting" issued by Ministry of Finance (2016).
} 
such as process management. GMAP (2016) summarized the major fields of management accounting functions as cost management, project management and so on. Hence, based on CGMA (2015) and GMAP (2016), the present study contends that the meaning of FBP should be participation of the finance department in the decision-making processes of a firm, including pricing, cost management, project management, budgeting, performance evaluation, financing, merging and acquisition, strategic tax management, process management, strategic objective determining, as well as risk control decisions.

With respect to the financial performance of the firm, previous studies have defined firms' performance from different perspectives such as profit margin (Zoni \& Merchant, 2007) and process improvement (Hoozee \& Ngo, 2017). However, their definitions of performance are not comprehensive and only cover one aspect of performance (financial or non-financial performance). In contrast, the present study posits that the performance measures of the firm should be comprehensive and encompass financial and non-financial as well as quantitative and qualitative measures. Consequently, following Mia and Clark (1999) and Zhang et al. (2017), firm performance in this study is defined as the degree to which a firm is successful in meeting its target performance, for instance, the accomplishment of goals related to cost, profit, sales volume, market share, customers and so on.

The discussion of the causal relationship between FBP and a firm's financial performance is as follows:

The results of many existing studies have demonstrated that the financial performance of firms can be enhanced by the employment of MACS, including improved profits, sales growth, and total return on assets, as well as reduced costs. Kennedy and Affleck-Graves (2001) conducted a comparative study of 47 companies that employed the activity-based costing $(\mathrm{ABC})$ system and 183 companies that did not use the $\mathrm{ABC}$ system. The sample firms were selected from the London Stock Exchange (LSE). The results showed that ABC users have better financial performance than $\mathrm{ABC}$ non-adaptors in terms of firm value. Their finding is supported by that of Cagwin and Bouwman (2002), who also found that financial performance is greatly influenced by ABC. An empirical study by Davis and Albright (2004) on firms in the United States also revealed that the banks that implemented a balanced scorecard technique achieved better financial performance than those that did not in terms of larger business volumes and higher income levels.

Previous studies have also shown that financial staffs adopting a business-oriented role could lead to the successful implementation of the MACS (Emsley, 2005). Thus, the present study also expects that the application of FBP might lead to the successful implementation of the MACS. For example, under the involvement of the finance department in decisionmaking, the firm can group the overhead costs into cost pools, identify key activities, select the cost drivers, and determine the method for allocating overhead costs more accurately; thus, $\mathrm{ABC}$ will be implemented more successfully. Additionally, with the finance department participating in operations, the accuracy of data supplied by the finance department can be substantially increased, which might facilitate the implementation of the MACS. Therefore, a higher level of perceived financial performance can be achieved.

However, a few previous studies also indicate that FBP will bring financial benefits to adaptors. For instance, the research of Zoni and Merchant (2007) on 17 large Italian firms 
demonstrated that the participation of financial controllers in the decision-making process will result in improved financial performance in terms of sales volume, operating profit and cost control. Furthermore, Kuye and Sulaimon (2011) demonstrated that among 670 Nigerian manufacturing firms, those that demonstrated involvement of employees in the decision-making process generated a higher performance in terms of profit and sales volume. Additionally, in a survey in Ireland, $28 \%$ of the respondents reported that they obtained substantial financial benefits by engaging in FBP (Flanagan \& Grant, 2013).

The present study contends that due to the involvement of the finance department in the decision-making process, FBP implementation is expected to allow non-finance and finance departments to share data sources, providing the finance staff with a full picture of the operation of the firms; hence, comprehensive monitoring, timely detection and reconciliation of conflicts between finance and non-finance departments will be effectively undertaken. Therefore, the data supplied by the financial accounting system will more accurately reflect the actual operations of the firm, top management will obtain more precise information for effective decision-making, and the quality of decisions will be enhanced. Furthermore, the role of the finance department would be changed from "recording business transactions or past events" to "advising business or providing internal consultation" and from traditional financial accounting to value creation. Additionally, the main task of the finance department would change from "supplying historical data" to "supporting business decisions". Therefore, operational risk will be minimized, processes will be optimized, and financial performance will also be improved.

In addition, FBP might eradicate the conflicts between finance and non-finance departments. There are always conflicts in the day-to-day operation of a firm because different departments of a firm are guided by different objectives. For cost control, business departments, such as sales departments, attempt to improve revenue without taking cost savings into consideration, while for cost savings, finance departments might implement tight control over the activities of staff from other departments, which may lead to conflicts between sales and finance departments. This conflict posits a negative impact on the productivity and effectiveness of the firm. Implementation of FBP, however, will encourage the finance and business departments to work together to achieve the same goals, and employee awareness of cost savings will be greatly enhanced. In effect, the operating costs of the firm will be greatly reduced, thereby increasing the operating profits and financial operations of the firm.

Furthermore, sales departments maintain different interests from those of finance departments. For instance, the sales department might consider capturing market share by lowering the selling price of a product; however, the finance department might believe that the selling price should exceed costs. This conflict might cause goal incongruences. By cooperating with non-finance departments, the finance department would understand that more customers will be attracted by lower prices, and a higher market share will be obtained. Therefore, longterm financial advantages will be achieved.

Hence, this study predicts that FBP implementation will have a positive and significant effect on the financial performance of firms. Consequently, the first hypothesis to be tested is as follows:

H1: A higher extent of FBP implementation results in a higher level of accomplishment of the goals related to the firm's financial performance. 


\subsection{Mediating effect of non-financial performance measures}

Existing studies on management accounting have commonly applied employees' performance (Kallunki et al., 2011; Lopez-Valeiras et al., 2018), internal process performance (Ittner, 2002; Kallunki et al., 2011; Duréndez et al., 2016) as well as market performance (Kallunki et al., 2011) as the important features for non-financial performance. Hence, Figure1 also shows the indirect relationship between the extent of the FBP implementation and the financial performance of the firm by considering three important non-financial types of performance of the firms (employee's performance, internal process performance, and market performance) as mediating variables. The reason for considering non-financial performance as a mediating variable is as follows:

Some scholars have claimed that the effect of MACS, such as ABC, BSC and benchmarking, on the financial performance of firms is indirect rather than direct, and certain nonfinancial indicators, such as internal processes, customer satisfaction, and market share, can play a mediating role in the relationship between MACS and financial performance of the firm (Chenhall \& Langfield-Smith, 1998; Ittner, 2002). The same argument can be extended to the involvement of the FBP in various decisions.

A major objective of this study is to extend the theory of current literature in the domain of FBP. Hence, by relying on the current literature and the following arguments, this study contends for the first time that non-financial performance information of the firm will mediate the relationship between FBP and financial performance of the firm. That is, in addition to the direct relationships and effect between the extent of the FBP implementation and financial performance of the firm, there is also an indirect relationship and effect between them via the non-financial variables. In the latter case, according to the literature on mediation (Baron \& Kenny, 1968; Namazi \& Namazi, 2016), a chain of causal relationship exists which start from FBP to the non-financial items and then from non-financial items to the firms' performance. Hence, non-financial performance is characterized as a mediating variable and can provide an explanation for the relationship between FBP and firm financial performance. Consequently, the following main mediating hypotheses $(\mathrm{Hm})$ are provided:

- Hma: The effect of FBP on the financial performance of the firm is mediated by the accomplishment of the goals related to employees' performance.

- Hmb: The effect of FBP on the financial performance of the firm is mediated by the accomplishment of the goals related to internal processes performance.

- Hmc: The effect of FBP on the financial performance of the firm is mediated by the accomplishment of the goals related to market performance.

The preceding hypotheses, however, should be detailed to reflect the nature of the nonfinancial measures in this context more unambiguously. As Figure 1 shows, a first link in the chain of causal relationships is from FBP to non-financial measures and the second link is from non-financial measures to financial performance of the firm. These relations and their respective hypotheses are provided as follows:

\subsection{The effect of FBP on non-financial performance}

In Figure 1, paths $\mathrm{H} 2 \mathrm{a}, \mathrm{H} 2 \mathrm{~b}$, and $\mathrm{H} 2 \mathrm{c}$ reveal the relationship between $\mathrm{FBP}$ and non-financial measures. To date, no studies have directly examined the association and effect of FBP on the 
non-financial performance of the manufacturing firms. However, past studies have revealed that enhanced non-financial performance, such as improved product or service quality, and market performance including increased customer satisfaction, market share, and delivery speed are affected by the introduction of MACS. For instance, Kallunki et al. (2011) found that the use of MACS can lead to the enhancement in non-financial performance, such as market share, employee satisfaction and internal process. Duréndez et al. (2016) conducted a survey of more than 900 small and medium enterprises (SMEs) in Spain and found that the use of MACS significantly improved non-financial performance in areas such as quality, customer satisfaction, and productivity of the sampled firms and that the enterprises that applied MACS had better performance in terms of the market share and productivity than the firms that did not use MACS.

A study of 170 Belgian firms by Hoozee and Ngo (2017) showed that the involvement of managers in the design of the cost system could contribute to process improvements, thereby improving the quality of products and reducing costs. A similar principle can be extended to the relationship between FBP implementation and the accomplishment of goals related to internal process performance. Hence, this study expects FBP to supply high-quality information (external and internal) and timely data, which will assist in the successful implementation of MACS. Consequently, the implementation of FBP is expected to generate a considerable association with and effect on the non-financial performance of firms (including employee's performance, internal process, and market share of the firm).

This study also assumes that the implementation of FBP indicates that finance staff and non-finance staff cooperate with each other to participate in various decision-making processes, such as investment decisions and financing decisions. Participation will create an elevated sense of ownership, employee enthusiasm will be increased, and employee skills, such as analytical skills and critical thinking skills, can also be further enhanced. These outcomes can ultimately affect non-financial measures. Furthermore, FBP implementation can resolve the confrontation between finance and non-finance departments, and goal congruence can be achieved. Eventually, the power of employees to implement decisions will also be significantly enhanced and the value of the non-financial aspects of the firm will be increased.

Past studies have also stressed that taking part in the decision-making procedures greatly enhances employees' feelings of competence (Hoozee \& Bruggeman, 2010; Hoozee \& Ngo, 2017). Hence, the current study considers that the FBP will motivate employees to participate in decision-making; therefore, the skills, overall satisfaction, and implementation power of employees will be enhanced, which will improve the non- financial performance of the firm. Thus, the following hypotheses are formulated:

- H2a: Greater FBP implementation leads to accomplishment of goals related to improved performance of the employees.

- H2b: Greater FBP implementation leads to accomplishment of goals related to improved performance of the firm's internal processes.

- H2c: Greater FBP implementation leads to accomplishment of goals related to improved market performance of the firm. 


\subsection{Effect of non-financial performance on financial performance}

Figure 1 also shows the relationship between the non-financial measures and financial performance of the firm via paths $\mathrm{H} 3 \mathrm{a}, \mathrm{H} 3 \mathrm{~b}$ and $\mathrm{H} 3 \mathrm{c}$. The existing literature supports this relation. For instance, studies on the balanced scorecard (BSC) technique (for example, Kaplan \& Norton, 1996; Iyibildiren \& Karasioglu, 2018) have unambiguously revealed that nonfinancial performance such as customer satisfaction, internal process improvement, and employees' growth of their skills and education, will affect the firm's financial performance.

Davila and Venkatachalam (2004) demonstrated that in the airline industry, non-financial measures provide incremental information about the firm's financial performance, and there is a significant relationship between the non-financial performance (the rate of the passenger loading) and CEO compensation plans after controlling for the firm's financial performance measures (return on assets and stock returns). Lau and Oger (2011), based on a survey of 60 French managers, concluded that non-financial performance measures could have one or two effects on the employees: 1) they could improve employees' perceptions regarding procedural fairness and/or 2) they could enhance employees' perceptions of procedural fairness. Hence, non-financial measures are positively related to employees' job satisfaction. These effects are indirect, occurring via the improvement of procedural fairness rather than by decreasing the role of the ambiguity function. Employees' job satisfaction will ultimately lead to the improvement of the financial affairs of the firm. Yuliansyah and Ahmad Razimi (2015) investigated the role of the non-financial factors on the performance of a firm listed on the Indonesia Stock Exchange and studied the significance of innovation as a mediating variable in this context. Their major finding is that non-financial measures significantly affect the firm's performance, which is fully mediated by innovation. Kamilah and Zabri (2016), based on an examination of 118 questionnaires relating to Malaysian manufacturing companies, found that non-financial measures have a considerable effect on the firm's internal processes efficiency as well as product development, growth, corporate social responsibility, and firm performance. Recently, Mjongwana and Kamala (2018) investigated the effects of non-financial measures on the performance of hotels in South Africa. They reported that the non-financial measures had mainly positive effects on improving the profitability, productivity and effectiveness of the business as well as enhancing the decision-making process. In addition, customer-oriented measures were perceived to be the most effective non-financial factor.

Based on the previous studies and arguments, this study considers that a causal relationship exists between firms' non-financial and financial performance in that improvement of the performance of the employees will have a positive and significant effect on the financial performance of the firm. The reasoning rests on the argument that employees' incentives can motivate them to participate in the decision-making process, share their knowledge, skills, and make value-creating decisions. Therefore, the skills, overall satisfaction, and implementation power of employees will be enhanced. These factors, in effect, will improve the firms' financial performance.

In addition, the improvement of the internal processes will result in increasing efficiency and productivity of the firm. As a result, among other benefits, manufacturing costs will be 
reduced, manufacturing cycle time will be further shortened, and customer satisfaction will be increased. Once the customers are satisfied, the market share and sales volume will be further increased. Finally, the firm might be more profitable. Hence, this study formulated the following hypothesis.

- H3a. Accomplishment of the goals related to performance of the employees will improve the financial performance of the firm.

- H3b. Accomplishment of the goals related to performance of the firm's internal processes will improve the financial performance of the firm.

- H3c. Accomplishment of the goals related to the market performance of the firm will improve the financial performance of the firm.

\section{Research design and methodology}

\subsection{Questionnaire design and research sample}

Numerous previous studies have examined the relationship between firm performance and MACS in a variety of sectors, such the banking sector (Davis \& Albright, 2004) and manufacturing sector (Ittner, 2002). The design of MACS also varies among industries. This paper focuses on the manufacturing sector of China for two reasons: the importance of manufacturing firms for China's economy and China's strategic goals as laid out in "China manufacturing 2025" and the presence of different management styles in different types of companies. Thus, FBP is also implemented in various forms. Studies by Ittner and Larcker (1997) and Messner (2016) showed that the relationship between the application of MACS and performance could be greatly influenced by the industry in which a firm operates. Additionally, the present study conducts surveys of only large manufacturing firms. Several studies have shown that large firms are more likely to adopt management accounting and control systems (Bjornenak, 1997; Innes et al., 2000; Chenhall, 2003); thus, this study considers that FBP is likely to be applied among large manufacturing firms. In China, one common criterion to determine the size of a firm is the number of employees. According to the SME promotion law issued by the Ministry of Industry and Information Technology of P. R. China in 2017, SMEs are firms with fewer than 2000 employees; hence, the present research adopted a cutoff of 2000 staff members to differentiate large firms from SMEs, and companies with fewer than 2000 employees were excluded from this study.

Research data were collected via survey questionnaires. Questionnaire-based surveys are regarded as the most suitable method for the current study, as they enable the collection of a large volume of data at a low cost (Shields, 1995; Gosselin, 1997). Additionally, questionnaire-based surveys can measure abstract issues that many databases cannot reflect (such as decision-making and control behaviour), making empirical studies more operative. In addition, this study expects a questionnaire-based survey method to be able to determine whether the theory guiding firm practice is appropriate and that the conclusions of field research and empirical research can be further examined by a questionnaire-based survey.

The first draft of the questionnaire was designed by the research group based on the literature on management accounting and organizational behaviour. To increase the validity of this research, the face validity approach was followed; hence, we invited two experts from the 
academic field to comment on the questionnaire and amended the survey according to the comments of the experts After the first amendment, this study conducted a pilot test before the final version of the questionnaire was sent to the target respondents. In the pilot test, CFOs from three different publicly listed companies were asked to respond to the questionnaire and make comments on its contents, particularly regarding the measurement of the main research variables. After the pilot test, final modifications of the questionnaire were made based on the comments and feedback of the three participants. Therefore, the quality of the questionnaire was enhanced.

The target questionnaire respondents were managing directors, chief finance officers, finance managers, and accounting supervisors, who maintain a clearer understanding and knowledge of the organizational structure of their firms and of the implementation of management accounting tools/control systems and the operation of their enterprise, which assist them in understanding the degree of the business and finance integration in their respective companies.

This study also used an online questionnaire. The questionnaires were distributed through a website called "China Accounting Vision", which is sponsored by the Shanghai National Accounting Institute (SNAI). The questionnaires were also sent to qualified students attending training courses such as "accounting talent leading class", "provincial and municipal excellent accounting talent training course", "General Accountant Training", EMBA, and EMPACC at the SNAI. All students were suitable for the current research.

\subsection{Measurement of research variables}

To minimize response errors, the measurements of the questionnaire were modified from previous empirical studies. The questionnaire employed a close-ended response approach, where the respondents were requested to rate a specific statement on a 5-point Likert scale.

Since no previous empirical studies have developed measures for FBP, this study attempted to develop indicators for the FBP based on the main practices in the field of management accounting: controlling, planning, coordination, evaluation and prescription of the CGMA (2015) and GMAP (2016). The respondents were asked to rate statements using the following scale: " 1 = Do not participate in the decision and do not understand it", " 2 = Do not participate in the decision but understand it", " $3=$ Neutral", " $4=$ Participate in the decision-making but have no voice in the final decision", " 5 = Participate in the decision-making and have a strong voice in the final decision". The respondents were asked to rate the preceding five statements regarding whether the finance staff participates in decisions regarding "Determining the strategic goal", "Project management", "Pricing", "Process management", "Risk control", "Performance evaluation", "Financing", "Merging and acquisition", "Cost management and transformation", "Strategic tax management", and "Budgeting". Higher values represent a higher degree of participation of the finance staff in the decision-making process in the investigated companies.

For the firm performance variables (including financial and non-financial performance), the measures were adapted from Mia and Clarke (1999) and Kallunki et al. (2011). The purpose of these measures is to examine whether the respondents achieve their target per- 
formance. The respondents were asked to answer on a 5 -point scale ranging from " $1=$ Not at all" to " 5 = To a great extent" regarding the accomplishment of goals related to financial performance (AGFP) and non-financial performance, including the accomplishment of goals related to employees' performance (AGEM), internal process performance (AGIPP), and market performance (AGMP). A higher value indicates a higher degree of achievement of planned performance.

\subsection{Research methodology}

This study is the first to examine the effect of FBP implementation (EFBPI) on firms' comprehensive performance, including financial and non-financial performance together, and the mediating role of non-financial performance on the relationship between FBP and financial performance. This study consists of one exogenous construct EFBPI and four endogenous constructs (accomplishment of goals related to employee performance (AGEP), internal business and market performance (AGBMP), and financial performance (FP)). All these constructs were measured based on observed variables.

Partial least squares structural equation modelling (PLS-SEM) was used in this study because it is widely used by researchers in accounting and other fields to examine the causal association and effect between unobservable variables (Mourad \& Valette-Florence, 2016). PLS-SEM has also been adopted in many research areas, such as management information systems, accounting, and operating management (Hair et al., 2014), for many reasons. First, it is suitable for studies with small sample sizes, multiple dependent variables and a large set of independent variables (Hair et al., 2014). Second, it is appropriate when a study is at the initial stage of theoretical development (Ribau et al., 2017). Third, PLS-SEM allows researchers to examine the measurement model concurrently with the structural model and permits scholars to employ more complicated research models with both mediating associations (Lee et al., 2011). In this paper, we used SMART-PLS 2.0 software.

This research undertakes the bootstrapping of PLS-SEM method to examine the significance of relationships and the adopted path coefficient suggested by Hair et al. (2006) to examine the mediating effect of non-financial performance on the relationship between FBP and financial performance.

\section{Results}

\subsection{Profile of respondents}

The instructions for the questionnaires clearly stated that the questionnaire should be completed by managing directors, chief financial officers, financial managers, or accounting supervisors; otherwise, the questionnaires would be excluded from data analysis. A total of 1,000 questionnaires were distributed to target respondents in 2018, and the collection of questionnaires lasted for almost 3 months; 125 questionnaires were successfully collected. However, 8 questionnaires were removed due to incompleteness or because they were completed by unsuitable people or by representatives of SMEs. Finally, a total of 117 valid questionnaires were included in the data analysis, demonstrating a response rate of $11.7 \%$. 
CFOs accounted for $41.9 \%$ of the total respondents, followed by financial managers (29.1\%), accounting supervisors (23.9\%), and chairmen or presidents (3.4\%), with managing directors accounting for the smallest number of the total respondents (1.7\%). In addition, $78.9 \%$ of the total respondents worked in their firms for more than 5 years.

The positions, work experience, and years of work of the respondents indicate that they have a deep understanding of the MACS design, daily operations and main activities of their enterprises; thus, they could clearly understand the questions in the research questionnaires. Hence, it could be ensured that the quality of the questionnaires for this study is reliable.

As for the distribution of the research samples, the percentages of firms located in northern, north-eastern, central, southern, and north-western China were 17 (14.5\%), 2 (1.7\%), 64 (54.7\%), 4 (3.4\%), 2 (1.7\%), 3 (2.6\%), and 11 (9.4\%), respectively. Hence, it can be concluded that the sample firms cover almost all regions of China.

\subsection{Scales of the variables}

Table 1 shows the loading information regarding the variables of the study. Smart-PLS was adopted to calculate the cross loadings of the scales for the main research variables.

Table 1. Scale of variables and loadings $(\mathrm{N}=117)$

\begin{tabular}{|c|c|c|c|}
\hline Variables & Scales & Cross loadings & Adapted from \\
\hline \multirow{5}{*}{$\begin{array}{l}\text { The extent of FBP } \\
\text { implementation } \\
\text { (EFBPI) }\end{array}$} & Process management & 0.804 & \multirow{5}{*}{$\begin{array}{l}\text { CGMA (2015), } \\
\text { GMAP (2016) }\end{array}$} \\
\hline & Strategic objective determining & 0.793 & \\
\hline & Pricing decision & 0.794 & \\
\hline & Project management & 0.809 & \\
\hline & Performance evaluation & 0.642 & \\
\hline \multirow{3}{*}{$\begin{array}{l}\text { Accomplishment } \\
\text { of goals relating } \\
\text { to financial } \\
\text { performance (AGFP) }\end{array}$} & $\begin{array}{l}\text { Accomplishment of goals } \\
\text { related to cost control }\end{array}$ & 0.813 & \multirow{9}{*}{$\begin{array}{l}\text { Mia and Clarke } \\
\text { (1999), } \\
\text { Kallunki et al. (2011) }\end{array}$} \\
\hline & $\begin{array}{l}\text { Accomplishment of goals } \\
\text { related to sales volume }\end{array}$ & 0.853 & \\
\hline & $\begin{array}{l}\text { Accomplishment of goals } \\
\text { related to profit }\end{array}$ & 0.865 & \\
\hline \multirow{3}{*}{$\begin{array}{l}\text { Accomplishment } \\
\text { of goals relating to } \\
\text { market performance } \\
\text { (AGMP) }\end{array}$} & $\begin{array}{l}\text { Accomplishment of goals } \\
\text { related to customer satisfaction }\end{array}$ & 0.835 & \\
\hline & $\begin{array}{l}\text { Accomplishment of goals } \\
\text { related to market share }\end{array}$ & 0.907 & \\
\hline & $\begin{array}{l}\text { Accomplishment of goals } \\
\text { related to new clients }\end{array}$ & 0.840 & \\
\hline \multirow{3}{*}{$\begin{array}{l}\text { Accomplishment } \\
\text { of goals relating } \\
\text { to internal process } \\
\text { performance } \\
\text { (AGIPP) }\end{array}$} & $\begin{array}{l}\text { Accomplishment of goals } \\
\text { related to service or product }\end{array}$ & 0.851 & \\
\hline & $\begin{array}{l}\text { Accomplishment of goals } \\
\text { related to the speed of delivery }\end{array}$ & 0.845 & \\
\hline & $\begin{array}{l}\text { Accomplishment of goals } \\
\text { related to the launch of new } \\
\text { products or service }\end{array}$ & 0.821 & \\
\hline
\end{tabular}


End of Table 1

\begin{tabular}{|c|c|c|c|}
\hline Variables & Scales & Cross loadings & Adapted from \\
\hline \multirow{3}{*}{$\begin{array}{l}\text { Accomplishment } \\
\text { of goals relating } \\
\text { to employee } \\
\text { performance(AGEP) }\end{array}$} & $\begin{array}{l}\text { Accomplishment of goals } \\
\text { related to employee satisfaction }\end{array}$ & 0.901 & \\
\hline & $\begin{array}{l}\text { Accomplishment of goals } \\
\text { related to the improvement of } \\
\text { implementation capacity }\end{array}$ & 0.839 & \\
\hline & $\begin{array}{l}\text { Accomplishment of goals } \\
\text { related to the enhancement of } \\
\text { skills }\end{array}$ & 0.900 & \\
\hline
\end{tabular}

Cross loading can be used for the assessment of convergent validity, and its value should be greater than 0.6 (Hair et al., 2014). Therefore, the indicators with cross loading less than 0.6 were excluded from analysis. As a result, for the variable EFBPI, only five indicators, namely, "process management decision", "strategic objective determination", "pricing decision", "project management decision", and "performance evaluation decision", were included in the data analysis.

\subsection{Descriptive analysis}

Table 2 presents the descriptive statistics of the main research variables, which reflects the EFBPI and the accomplishment of the target performance of the surveyed companies.

Table 2. Descriptive statistics of research variables $(\mathrm{N}=117)$

\begin{tabular}{|c|c|c|c|c|}
\hline Variables & Mean & S. D & Max & Min \\
\hline EFBPI & 3.576 & 0.944 & 5 & 1 \\
\hline AGFP & 3.348 & 0.923 & 5 & 1 \\
\hline AGEP & 3.031 & 0.706 & 5 & 1 \\
\hline AGIPP & 2.909 & 0.920 & 5 & 1 \\
\hline AGMP & 3.066 & 0.842 & 5 & 1 \\
\hline
\end{tabular}

The mean value for the extent of FBP implementation (EFBPI) is 3.576. Also, the mean score for process management, strategic management determining, pricing decision, project management, performance evaluation are 3.453, 3.642, 3.367, 3.851, and 3.772 respectively. It indicates that the value selected by the respondents is higher than the average. It also suggests that the finance department not only possesses a certain understanding of business activities but also maintains a certain degree of participation in the decision-making process. However, the finance departments still have no authority to determine the final decision; therefore, the participation of the finance department among the sampled firms can be considered only as moderate.

With respect to firm performance, only the mean score for accomplishment of the goals related to financial performance (AGFP) was higher than average (3.348). Accomplishment of goals related to employee performance (AGEP), accomplishment of goals related to market 
performance (AGMP) and accomplishment of goals related to internal processes performance (AGIPP) were 3.031, 3.066 and 2.909 respectively, which means that the achievement of goals related to financial and non-financial performance were above the average (except AGIPP, which was slightly below average).

\subsection{Measurement of the research model}

In this study, the measurement model was assessed in terms of reliability, convergent validity, and discriminant validity. Table 3 presents the values of AVE, composite reliability, Cronbach's alpha, and communality of all the reflective constructs.

Table 3. Reliability and validity $(\mathrm{N}=117)$

\begin{tabular}{|c|c|c|c|c|c|c|}
\hline $\begin{array}{c}\text { Research } \\
\text { variables }\end{array}$ & AVE & $\begin{array}{c}\text { Composite } \\
\text { Reliability }\end{array}$ & R Square & Cronbach's a & $\begin{array}{c}\text { Commu- } \\
\text { nality }\end{array}$ & $\begin{array}{c}\text { Square root } \\
\text { of AVE }\end{array}$ \\
\hline EFBPI & 0.595 & 0.879 & & 0.833 & 0.595 & 0.771 \\
\hline AGFP & 0.712 & 0.881 & 0.425 & 0.798 & 0.712 & 0.844 \\
\hline AGEP & 0.775 & 0.911 & 0.071 & 0.856 & 0.775 & 0.880 \\
\hline AGMP & 0.640 & 0.826 & 0.164 & 0.826 & 0.742 & 0.861 \\
\hline AGIPP & 0.705 & 0.791 & 0.141 & 0.791 & 0.705 & 0.839 \\
\hline
\end{tabular}

As Table 3 shows, the value of Cronbach's alphas for the main research variables ranges from 0.791 to 0.856 , with all exceeding the minimum level (0.70) suggested by Nunnally (1978), indicating that the scales can be considered satisfactory in this research.

The validity of the questionnaire was assessed in terms of convergent validity and discriminant validity, as recommended by Hair et al. (2014). The criteria for acceptable convergent validity are across loading greater than 0.6 (Hair et al., 2006), a composite reliability greater than 0.6 (Hair et al., 2014), a communality score greater than 0.5 (Hair et al., 2013), and an average value extracted (AVE) greater than 0.5 (Fornell \& Laker, 1981). As shown in Tables 1 and 3, the values of the cross loadings, composite reliability, communality, and AVE range from 0.642 to $0.907,0.791$ to $0.911,0.595$ to 0.775 and 0.595 to 0.775 , respectively; hence, the convergent validity for this study can be ensured.

The discriminant validity of the questionnaire was assessed according to Fornell and Larcker (1981). They suggest that the discriminant validity can be evaluated by comparing the value of the square root of the AVE and the coefficients between the main variables. The statistics in Tables 3 and 4 show that the values of the square root of the AVE are greater than the correlation coefficients of each variable; in addition, the score of correlation coefficient among each variable is lower than the value of their corresponding Cronbach's alpha, which suggests an acceptable level of discriminant validity of the research.

Table 4 presents the correlation between the main research variables. Table 4 shows that the correlation between each pair of variables is positive and significant, indicating that the extent of FBP implementation (EFBPI) is positively associated with the accomplishment of goals related to financial performance (AGFP), employee's performance (AGEP), market performance (AGMP), and internal process performance (AGIPP). It also shows that the 
target non-financial performance also correlates with target financial performance. Thus, preliminary support for all the research hypotheses in this study is provided. Additionally, the value of the correlation coefficient among the research variables below the score of 0.9 (Pallant, 2001) and the value of variance inflation factor (VIF) between the independent variables are all less than the critical value of 10 (Hair et al., 2014), suggesting that there is no multi-collinearity problem in this study.

Table 4. Correlation from PLS model $(\mathrm{N}=117)$

\begin{tabular}{|c|c|c|c|c|c|c|}
\hline Variables & EFBPI & AGFP & AGMP & AGIPP & AGEP & VIF \\
\hline EFBPI & 1 & & & & & 1.271 \\
\hline AGFP & $0.324^{\star *}$ & 1 & & & & N/A \\
\hline AGMP & $0.405^{\star *}$ & $0.644^{\star *}$ & 1 & & & 2.436 \\
\hline AGIPP & $0.375^{* *}$ & $0.475^{* *}$ & $0.769^{* *}$ & 1 & & 2.562 \\
\hline AGEP & $0.266^{* *}$ & $0.333^{* *}$ & $0.433^{* *}$ & $0.480^{* *}$ & 1 & 1.511 \\
\hline
\end{tabular}

Notes: ${ }^{\star *}$ significant at 0.05 level (two tailed).

\subsection{The results of hypothesis testing}

In this study, bootstrapping was applied to examine the research hypotheses, which is an effective method for identifying the mediation effect of the variables employee's performance (AGEP), market performance (AGMP) and internal process performance (AGIPP) (Ribau et al., 2017; Hair et al., 2014). The final results of the hypothesis testing are reported in Table 5 and Figure 2. Table 5 summarizes the path coefficients between each research variable and the degree of their significance. The path coefficient is a reflection of the direction and strength of two variables, and for two variables, a significant relationship can be assessed by their respective $\mathrm{T}$ value. The results show that the $\mathrm{T}$ value exceeds 1.96 , indicates that a significant relationship exists among variables of the study (Hair et al., 2014).

The relationship between the EFBPI and accomplishment of goals relating to the financial performance (AGFP) is positive but not significant $(\beta=0.075 ; \mathrm{T}=0.893$ ); thus, Hypothesis 1 is not validated by the results.

Table 5. Results from PLS analysis $(\mathrm{N}=117)$

\begin{tabular}{|l|c|c|l|c|c|}
\hline & Path Coefficients & T-value & & Path coefficients & T-value \\
\hline EFBPI->AGFP & 0.075 & 0.893 & EFBPI ->AGEP & 0.266 & 3.423 \\
\hline EFBPI->AGMP & 0.405 & 4.316 & EFBPI->AGIPP & 0.375 & 4.167 \\
\hline AGEP->AGFP & 0.065 & 0.492 & AGIPP->AGFP & -0.085 & 0.625 \\
\hline AGMP-AGFP & 0.651 & 4.297 & & & \\
\hline
\end{tabular}

The findings of this study also indicated a positive and significant relationship between the EFBPI and the accomplishment of the goals related to employee performance (AGEP) $(\beta=0.266 ; \mathrm{T}=3.423)$, internal process performance (AGIPP) $(\beta=0.375 ; \mathrm{T}=4.167)$, as 
well as market performance $(\beta=0.405$; $\mathrm{T}=4.316)$. The results indicate that greater FBP implementation in a firm results in significantly increased employee motivation, skills and implementation power and will improve firm performance in terms of quality, productivity, innovation, customer satisfaction, and market share. Therefore, Hypotheses H2a, H2b and $\mathrm{H} 2 \mathrm{c}$ are supported.

Additionally, results for the examination of Hypotheses $\mathrm{H} 3 \mathrm{a}, \mathrm{H} 3 \mathrm{~b}$ and $\mathrm{H} 3 \mathrm{c}$ demonstrate that only accomplishment of goals related to market performance (AGMP) significantly and positively influences the target financial performance (AGFP). Hence, Hypothesis $\mathrm{H} 3 \mathrm{c}$ is supported, while Hypotheses $\mathrm{H} 3 \mathrm{a}$ and $\mathrm{H} 3 \mathrm{~b}$ are not supported.

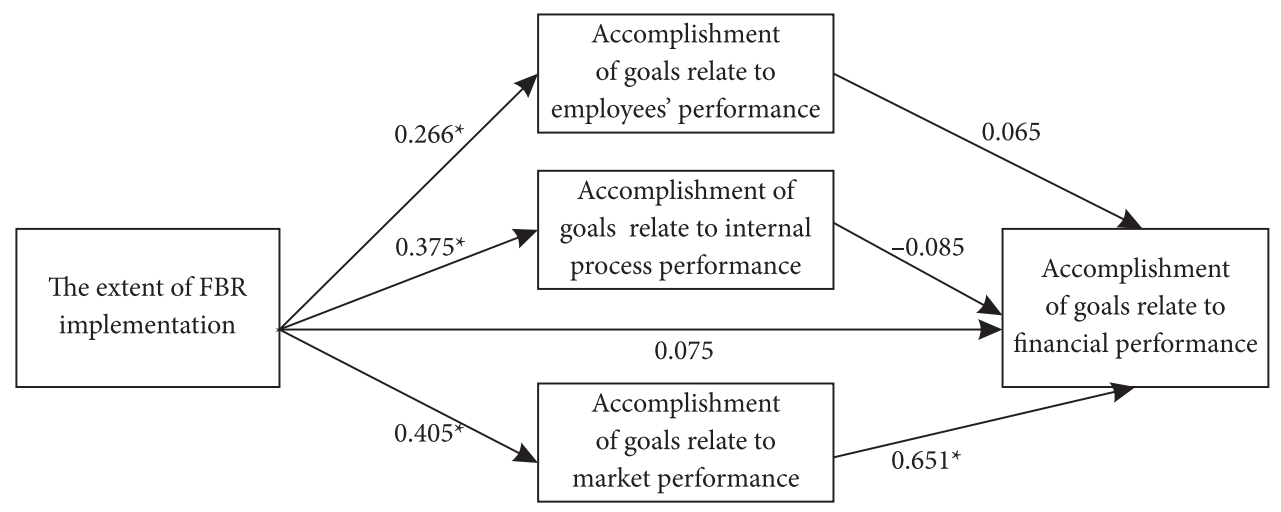

Note: ${ }^{\star}$ is significant at the 0.05 level.

Figure 2. Structural model

Table 6. Mediation analysis by PLS $(\mathrm{N}=117)$

\begin{tabular}{|l|c|c|c|}
\hline \multicolumn{1}{|c|}{ Path } & Direct effect & Indirect effect & Total effect \\
\hline EFBPI-> AGEP & 0.266 & - & 0.266 \\
\hline EFBPI->AGMP & 0.405 & - & 0.405 \\
\hline EFBPI->AGIPP & 0.375 & - & 0.375 \\
\hline EFBPI-> AGEP->AGFP & 0.075 & 0.017 & 0.092 \\
\hline EFBPI->AGMP->AGFP & 0.075 & 0.264 & 0.339 \\
\hline EFBPI->AGIPP->AGFP & 0.075 & 0.032 & 0.107 \\
\hline
\end{tabular}

As shown in Tables 5 and 6, the relationship between target employee performance, target internal process performance and target financial performance is not remarkable, According to the method proposed by Hair et al. $(2006,2017)$, the relationship between FBP implementation and target financial performance is not mediated by employee performance and internal process performance. Hence, Hypothesis Hma and Hypothesis Hmb are not supported.

The indirect effect of FBP implementation on financial performance through the target performance of market performances is 0.264 . According to Hair et al. (2006), if the value of the indirect effect exceeds 0.08 , a mediating effect is evident. Therefore, attaining market 
performance goals will play a full mediating role in the association between FBP implementation and target financial performance.

Moreover, the results of the mediating test can also be confirmed by the use of variance accounted for (VAF) (Hair et al., 2014; Ribau et al., 2017). VAF can be calculated by the total indirect effect divided by the total effect. In this study, the VAF for the path between target market performance and financial performance is $85 \%$; hence, a mediating effect of market performance on the association between FBP and target financial performance is obvious, and consequently, Hypothesis Hmc is supported.

\section{Discussion}

The primary objective of this manuscript was to answer the question, "Can the implementation of FBP improve firms' performance? The findings of this study demonstrate that 1) the degree of integration between finance and business was moderate among the sampled manufacturing firms; 2) the extent of FBP implementation does not play a significant role in improving target financial performance; 3) FBP implementation is significantly and positively correlated with the accomplishment of goals related to internal processes, market performance, and employee performance; and 4) target market performance plays a mediating role in the association between the FBP implementation and target financial performance. Therefore, the answer to the primary question is as follows: FBP implementation can improve non-financial performance but does not play a significant role in improving financial performance directly. The sampled firms achieved only a moderate level of non-financial performance because of the moderate level of FBP implementation.

This finding is similar to the results of numerous previous studies that failed to find a direct relationship between MACS and financial performance (Kennedy et al., 2001; Banker et al., 2008; Kallunki et al., 2011). This study posits that the financial performance of firms might be affected by numerous variables, including inflation, politics, economic cycle, and the strategies adopted by companies. Therefore, it is difficult to determine whether the improved performance is due to FBP implementation. In addition, improved financial performance might be a product of the length of FBP implementation; that is, the longer FBP has been implemented, the higher the achievement of financial performance goals. Zoni and Merchant (2007) also found that the long-term financial performance of firms rather than short-term performance is impacted remarkably by the participation of controller in decision-making among Italian firms. It is can be concluded that similar to MACS, the effect of FBP on the financial performance of enterprises might not be direct and might be long term. This may be also related to the ambiguity of the role of FBP in the organization.

The findings of this study are also consistent with a number of prior studies, which found that participation in decision-making can enhance employees' motivation and competencies (Hoozee \& Ngo, 2017; Hoozee \& Bruggeman, 2010). In addition, the remarkable association between FBP and market performance indicates that involvement of the financial staff in the decision-making process, such as pricing decisions, improves the quality of pricing decisions, thereby greatly enhancing customer satisfaction and improving market performance. Thus, the effect of the goals related to the market performance with the financial performance of 
the firm is positive and significant. However, the effect of the goals relating to employee's performance and internal process of the firm is not significant. A possible reason for these latter findings might be due to the complexity and ambiguity role of defining these factors and determining their exact effects in the organizations. The same arguments can be extended with respect to the non-significant relationship of the mediating effect of the Hma and Hmb.

Furthermore, the findings of this study are also consistent with previous studies that found a mediating effect of non-financial performance (Kallunki et al., 2011), and the same principle can be extended to FBP. This study views that FBP implementation improves customer satisfaction and increases the number of repeated and new customers and that eventually, the improved market performance will result in improved financial performance.

\section{Conclusions}

This research contributes to the existing studies on FBP. It first attempts to construct the indicators to measure FBP based on the function of management and comprehensively examine the extent of FBP implementation; thus, the awareness of FBP and its potential benefits, such as the effect of FBP on firms' performance, is cultivated, and guidance for management to effectively implement FBP is also provided.

Second, by comprehensively examining the effect of FBP implementation on performance, the current study enriches the theory and literature related to the association between FBP and performance. Third, this study reports FBP affects firms' financial performance by mediating non-financial measures. Hence, the existing knowledge regarding how management can formulate FBP in improving performance is improved and upgraded. Finally, this study provides vivid empirical evidence concerning the effect of FBP and non-financial measures on firms' financial performance. This, in effect, contributes to a greater understanding of the application of contingency theory in the domain of manufacturing performance evaluation systems.

Based on the results of Table 5 and 6, this research also has managerial and organizational implications. First, due to the moderate level of FBP implementation, we suggest that manufacturing firms take various measures to ensure that finance business partnering is implemented successfully. Therefore, top management of companies should provide strong support for integrating finance and business, e.g., by providing employees with relevant training programs and recruiting new staff members with clear knowledge and understanding of FBP.

Second, the results of this study demonstrated that the extent of finance and business partnering has a positive and significant effect on employee performance. Therefore, manufacturing firms should motivate both financial staff and non-financial staff to participate in FBP implementation. Top management should consider linking performance evaluation and reward systems to FBP implementation. For instance, the performance measure for financial staff should include measures of company activities, such as their knowledge of firm operation, and a performance evaluation system for non-financial staff might include financial issues, such as the issue of cost savings. This study conjectures that when employee motivation is improved, employee skills will be enhanced, and employee performance will eventually be increased. 
Third, the results of this study indicate that the effect of FBP implementation on financial performance is indirect rather than direct. Therefore, manufacturing firms should not pay excessive attention to financial indicators when assessing the success of FBP implementation, especially at the early stage of FBP implementation. Top management should first consider non-financial indicators, such as quality, productivity, and employee skills. Excessive focus on financial indicators might lead to short-sighted behaviours of management and eventually result in failed finance business partnering, and it will also lead to an imbalanced performance evaluation system.

This study is subject to certain limitations. First, due to the limitation of the sampling, the generalizability of the results is limited. A second limitation is related to the scale of variables. Third, respondents of this study are limited to manufacturing firms. Therefore, the validity of the results for other samples is limited and must be considered with care. Fourth, this paper only considered finance staff as respondents, and potential bias might be exist. Finally, this study used cross-sectional data to test the relationship between variables; the effect of the length of FBP implementation on the firms' performance might have been overlooked.

Due to the limitations of current study, we also provide some suggestions for future researches. First, this study only used 117 completed questionnaires to conduct data analysis, the findings might not be generalized to other manufacturing firms, thus, case study or field study are desirable to conducted as the supplementary for survey method. Second, this study is an exploratory study and some of the measures and scales applied are not examined empirically. future studies are suggested to develop sets of measures from different perspectives, such as delivering necessary information, providing support, analysis and so on, allowing for the accurate investigation of the implementation of FBP. Third, this study focuses on manufacturing firms only, hence, future studies might consider selecting samples from non-manufacturing industries, such as financial and construction industries should be investigated by the future researches. Fourth, questionnaires only sent to finance staffs, therefore, future study should consider collecting research data from non-finance departments. Finally, the length of FBP implementation might affect firms' performance, thus, future studies are suggested to examine whether firms with a longer history of FBP achieve better financial performance than those not applying FBP.

\section{Acknowledgements}

All the authors named in the acknowledgments agree to being named.

\section{Funding}

This work was supported by (Ministry of Education of China, Project of Humanities and Social Sciences) under grant [19YJC630147]; and <Shandong Provincial Social Science Planning Project> under grant [19DGLJ07]. 


\section{Author contributions}

Zhang Yi Fei and Guo Yong Qing conceived the study. Zhang Yi Fei was responsible for writing this manuscript; Guo Yong Qing was responsible for making the revision; Namazi cooperate with the first author to revise the paper after receive the comments from reviewers, and he makes great contributions to this manuscript; Li Xuan was responsible for survey questionnaire distribution and collection, as well as data analysis.

\section{Disclosure statement}

We declare that our paper does not have any competing financial, professional, or personal interests from other parties.

\section{References}

Achim, M.-V., Borlea, S.-N., \& Mare, C. (2016). Corporate governance and business performance: Evidence for the Romanian Economy. Journal of Business Economics and Management, 17(3), 458-474. https://doi.org/10.3846/16111699.2013.834841

Baron, R. M., \& Kenny, D. A. (1986). The moderator-mediator variable distinction in social psychological research: Conceptual, strategic, and statistical considerations. Journal of Personality and Social Psychology, 51(6), 1173-1182. https://doi.org/10.1037/0022-3514.51.6.1173

Banker, R. D., Bardhan, I. R., \& Chen, T.-Y. (2008). The role of manufacturing practices in mediating the impact of activity-based costing on plant performance. Accounting, Organizations and Society, 33(1), 1-19. https://doi.org/10.1016/j.aos.2006.12.001

Bjornenak, T. (1997). Diffusion and accounting: The case of ABC in Norway. Management Accounting Research, 8(1), 3-17. https://doi.org/10.1006/mare.1996.0031

Burns, J., \& Baldvinsdottir, G. (2005). An institutional perspective of accountants' new roles - the interplay of contradictions and praxis. European Accounting Review, 14(4), 725-757. https://doi.org/10.1 080/09638180500194171

Cagwin, D., \& Bouwman, M. (2002). The association between activity-based costing and improvement in financial performance. Management Accounting Research, 13(1), 1-39.

https://doi.org/10.1006/mare.2001.0175

Chartered Global Management Accountant. (2015). Finance business partnering: The conversations that count (CGMA Report, pp. 1-23).

Chenhall, R. H. (2003). Management control systems design within its organizational context: Findings from contingency-based research and directions for the future. Accounting, Organizations and Society, 28(2), 127-168. https://doi.org/10.1016/S0361-3682(01)00027-7

Chenhall, R. H., \& Langfield-Smith, K. (1998). The relationship between strategic priorities, management techniques and management accounting: an empirical investigation using a systems approach. Accounting, Organizations and Society, 23(3), 243-264. https://doi.org/10.1016/S0361-3682(97)00024-X

Churchill, G. (1979). A paradigm for developing better measures of marketing constructs. Journal of Marketing Research, 16(1), 64-73. http://doi.org/10.2307/3150876

Ciftci, I., Tatoglu, E., Wood, G., Demirbag, M., \& Zaim, S. (2019). Corporate governance and firm performance in emerging markets: Evidence from Turkey. International Business Review, 28(1), 90-103. https://doi.org/10.1016/j.ibusrev.2018.08.004 
Davila, A., \& Venkatachalam, M. (2004). The relevance of non-financial performance measures for CEO compensation: Evidence from the airline industry. Review of Accounting Studies, 9, 443-464. https://doi.org/10.1007/s11142-004-7792-8

Davis, S., \& Albright, T. (2004). An investigation of the effect of Balanced Scorecard implementation on financial performance. Management Accounting Research, 15(2), 135-153. https://doi.org/10.1016/j.mar.2003.11.001

Duréndez, A., Ruíz-Palomo, D., García-Pérez-de-Lema, D., \& Diéguez-Soto, J. (2016). Management control systems and performance in small and medium family firms. European Journal of Family Business, 6(1), 10-20. https://doi.org/10.1016/j.ejfb.2016.05.001

Emsley, D. (2005). Restructuring the management accounting function: A note on the effect of role involvement on innovativeness. Management Accounting Research, 16(2), 157-177. https://doi.org/10.1016/j.mar.2005.02.002

Fisher, J. (1995). Contingency-based research on management control systems: Categorization by level of complexity. Journal of Accounting Research, 14, 24-53.

Flanagan, A., \& Grant, N. (2013). Finance business partner turning heads. Accountancy Ireland, 45(3), 47-49.

Fornell, C., \& Larcker, D. F. (1981). Structural equation models with unobservable variables and measurement errors: Algebra and statistics. Journal of Marketing, 18(3), 382-388. https://doi.org/10.1177/002224378101800313

Global Management Accounting Principles (GMAP). (2016). Effective management accounting improving decisions and building successful organizations (pp. 1-54).

Gosselin, M. (1997). The effect of strategy and organizational structure on the adoption and implementation of activity-based costing. Accounting, Organizations and Society, 22(2), 105-122. https://doi.org/10.1016/S0361-3682(96)00031-1

Graham, A., Davey-Evans, S., \& Toon, I. (2012). The developing role of the financial controller: Evidence from the UK. Journal of Applied Accounting Research, 13(1), 71-78. https://doi.org/10.1108/09675421211231934

Hair, J. F., Anderson, R. E., Tatham, R. L., \& Black, W. C. (2006). Multivariate data analysis (6 ${ }^{\text {th }}$ ed.). Prentice Hall.

Hair, J. F., Hult, G. T. M., Ringle, C. M., \& Sarstedt, M. (2017). A primer on partial least squares structural equation modeling (PLS-SEM) ( $2^{\text {nd }}$ ed.). Sage. https://doi.org/10.15358/9783800653614

Hair, J. F., Ringle, C. M., \& Sarstedt, M. (2014). Partial least squares structural equation modeling: Rigorous applications, better results and higher acceptance. Long Range Planning, 46(1), 1-12. https://doi.org/10.1016/j.lrp.2013.01.001

Hasan, I., Kobeissi, N., Liu, L., \& Wang, H. (2018). Corporate social responsibility and firm financial performance: The mediating role of productivity. Journal of Business Ethics, 149(3), 671-688. https://doi.org/10.1007/s10551-016-3066-1

Hoozée, S., \& Bruggeman, W. (2010). Identifying operational improvements during the design process of a time-driven $\mathrm{ABC}$ system: The role of collective worker participation and leadership style. Management Accounting Research, 21(3), 185-198. https://doi.org/10.1016/j.mar.2010.01.003

Hoozée, S., \& Ngo, Q.-H. (2017). The impact of managers' participation in costing system design on their perceived contributions to process improvement. European Accounting Review, 27(4), 747770. https://doi.org/10.1080/09638180.2017.1375417

Hussain, N., Rigoni, U., \& Orij, R. P. (2018). Corporate governance and sustainability performance: Analysis of tripe bottom line performance. Journal of Business Ethics, 149(2), 411-432. https://doi.org/10.1007/s10551-016-3099-5 
Indjejikian, R. J., \& Mate ${ }^{\vee}$ jka, M. (2006). Organizational slack in decentralized firms: The role of business unit controllers. The Accounting Review, 81(4), 849-872. https://doi.org/10.2308/accr.2006.81.4.849

Innes, J., Mitchell, F., \& Sinclair, D. (2000). Activity-based costing in the U.K’s largest companies: A comparison of 1994 and 1999 survey results. Management Accounting Research, 11(3), 349-362. https://doi.org/10.1006/mare.2000.0135

Ittner, C. D. (2002). The association between activity-based costing and manufacturing performance. Journal of Accounting Research, 40(3), 711-726. https://doi.org/10.1111/1475-679X.00068

Ittner, C. D., \& Larcker, D. F. (1997). The performance effects of process management techniques. Management Science, 43(4), 522-534. https://doi.org/10.1287/mnsc.43.4.522

Iyibildiren, M., \& Karasioglu, F. (2018). Balanced scorecard in business performance measurement and its effect on financial structure. Global Journal of Management and Business Research Finance, $18(2), 13-21$.

Jarvenpaa, M. (2007). Making business partners: A case study on how management accounting culture was changed AU. European Accounting Review, 16(1), 99-142. https://doi.org/10.1080/09638180701265903

Kallunki, J.-P., Laitinen, E. K., \& Silvola, H. (2011). Impact of enterprise resource planning systems on management control systems and firm performance. International Journal of Accounting Information Systems, 12(1), 20-39. https://doi.org/10.1016/j.accinf.2010.02.001

Kamilah, A., \& Zabri, S. M. (2016). The effect of non-financial performance measurement system on firm performance. International Journal of Economics and Financial Issues, 6(S6), 50-54.

Kaplan, R. S., \& Norton, D. P. (1996). The balanced scorecard: Translating strategy into action. Harvard University Press.

Kennedy, T., \& Affleck-Graves, J. (2001). The impact of activity-based costing techniques on firm performance. Journal of Management Accounting Research, 13(1), 19-45.

https://doi.org/10.2308/jmar.2001.13.1.19

Kuye, O., \& Sulaimon, A.-H. (2011). Employee involvement in decision making and firms performance in the manufacturing sector in Nigeria. Serbian Journal of Management, 6(1), 1-15. https://doi.org/10.5937/sjm1101001K

Lau, C. M., \& Oger, B. (2011). Non-financial performance measures on employee behaviours. Centre for Pacific Basin Business, Economics, and Finance Research, Airiti Press.

Lee, L., Petter, S., Fayard, D., \& Robinson, S. (2011). On the use of partial least squares path modelling in accounting research. International Journal of Accounting Information Systems, 12(4), 305-328. https://doi.org/10.1016/j.accinf.2011.05.002

Lopez-Valeiras, E., Gomez-Conde, J., \& Lunkes, R. J. (2018). Employee reactions to the use of management control systems in hospitals: Motivation vs. threat. Gaceta Sanitaria, 32(2), 129-134. https://doi.org/10.1016/j.gaceta.2016.12.003

McAdam, R., Miller, K., \& McSorley, C. (2019). Towards a contingency theory perspective of quality management in enabling strategic alignment. International Journal of Production Economics, 207, 195-209. https://doi.org/10.1016/j.ijpe.2016.07.003

Messner, M. (2016). Does industry matter? How industry context shapes management accounting practice. Management Accounting Research, 31, 103-111. https://doi.org/10.1016/j.mar.2015.09.001

Mia, L., \& Clarke, B. (1999). Market competition, management accounting systems and business unit performance. Management Accounting Research, 10(2), 137-158.

https://doi.org/10.1006/mare.1998.0097

Mjongwana, A., \& Kamala, P. N. (2018). Non-financial performance measurement by small and medium sized enterprise operating in the hotel industry in the city of Cape Town. African Journal of Hospitality, Tourism and Leisure, 7(1), 1-26. 
Mourad, S., \& Valette-Florence, P. (2016). Improving prediction with POS and PLS consistent estimations: An illustration. Journal of Business Research, 69(10), 4675-4684. https://doi.org/10.1016/j.jbusres.2016.03.057

Namazi, M., \& Namazi, N.-R. (2016). Conceptual analysis of moderator and mediator variables in business research. Procedia Economics and Finance, 36, 540-554. https://doi.org/10.1016/S2212-5671(16)30064-8

Nunnally, J. C. (1978). Psychometric theory. McGraw-Hill.

Pallant, J. (2001). SPSS survival manual-astep by step guide to data analysis. Open University Press.

Ribau, C. P., Moreira, A. C., \& Raposo, M. (2017). SMEs innovation capabilities and export performance: An entrepreneurial orientation view. Journal of Business Economics and Management, 18(5), 920-934. https://doi.org/10.3846/16111699.2017.1352534

Shields, M. (1995). An empirical analysis of firms' implementation experiences with activity-based costing. Journal of Management Accounting Research, 7, 148-161.

Sun, W., Zhao, C., \& Cho, C. H. (2019). Institutional transitions and the role of financial performance in CSR reporting. Corporate Social Responsibility and Environmental Management, 26(2), 367-376. https://doi.org/10.1002/csr.1688

Yuliansyah, Y., \& Ahmad Razimi, M. S. (2015). Non-financialperformance measures and managerial performance: The mediation role ofinnovation in an Indonesian stock exchange-listed organization. Problems and Perspectives in Management, 13(4), 135-144.

Zhang, Y. F., Namazi, M., \& Isa, C. R. (2017). Investigating the empirical effect of ABC stages on the performance of companies. Iranian Journal of Management Studies, 10(1), 175-205. https://doi.org/10.22059/IJMS.2017.216695.672286

Zoni, L., \& Merchant, K. A. (2007). Controller involvement in management: an empirical study in large Italian corporations. Journal of Accounting \& Organizational Change, 3(1), 29-43. https://doi.org/10.1108/18325910710732849 